\title{
OPEN \\ ACCESS \\ The Effect of Compensation and Workload on Loyalty Employees at Hotel Tanjung Surabaya
}

Hilda Yunita Wono Ismojo Herdono Jefferson Ronaldo

\section{INSTITUTION}

Universitas Ciputra Surabaya CBD Boulevard Citraland, Surabaya

\section{PHONE}

EMAIL

hilda.yunita@ciputra.ac.id

\section{DOI}

https://www.doi.org/

10.37010/prop.v1i1.250

\section{PAPER PAGE}

1-11

PROPAGANDA is a Journal of Communication Studies which is publish twice a year on January and July. PROPAGANDA is a scientific publication media in the form of conceptual paper and field research related to communication studies. It is hoped that PROPAGANDA can become a media for academics and researchers to publish their scientific work and become a reference source for the development of science and knowledge.

\author{
Pengaruh Kompensasi dan Beban Kerja terhadap \\ Loyalitas Karyawan di Hotel Tanjung Surabaya
}

\begin{abstract}
Semakin banyaknya kunjungan berwisata yang dilakukan di Indonesia, tentu harus diimbangi dengan bertambahnya hotel-hotel di Indonesia. Salah satunya di Surabaya, di kota tersebut banyak hotel dari yang tidak berbintang hingga berbintang dibangun di kota tersebut. Penelitian ini bertujuan untuk mengetahui apakah beban kerja dan kompensasi mempengaruhi loyalitas karyawan di Hotel Tanjung Surabaya. Teknik pengambilan data yang digunakan yaitu sampling jenuh, di mana sampel yang diambil dari seluruh populasi. Sampel yang digunakan dalam penelitian sebanyak 30 responden. Penelitian tersebut menggunakan metode kuantitatif, metode pengumpulan data menggunakan sedikit wawancara dan kuesioner dengan menggunakan skala Likert. Data dianalisis menggunakan software yang bernama Statistical Package for the Social Sciences (SPSS). Hasil penelitian ini membuktikan bahwa kompensasi dan beban kerja berpengaruh positif signifikan terhadap loyalitas karyawan.
\end{abstract}

The increasing number of tourist visits made in Indonesia, of course, must be balanced with the increase in hotels in Indonesia. One of them is in Surabaya, in that city many hotels, from non-star to five-star, are built in the city. This study aims to determine whether workload and compensation affect employee loyalty at Hotel Tanjung Surabaya. The data collection technique used is saturated sampling, where samples are taken from the entire population. The sample used in the study was 30 respondents. This research uses quantitative methods, data collection methods use a few interviews and questionnaires using a Likert scale. Data were analyzed using software called Statistical Package for the Social Sciences (SPSS). The results of this study prove that compensation and workload have a significant positive effect on employee loyalty.

\section{KEYWORD}

loyalitas, kompensasi, beban kerja

loyalty, compensation, workload 


\section{PROPAGANDA}

\section{PENDAHULUAN}

Di era sekarang ini industri pariwisata menjadi salah satu kebutuhan atau gaya hidup untuk masyarakat maju dan berkembang. Dalam Kamus Besar Bahasa Indonesia (KBBI) pariwisata memiliki arti yaitu sebuah kegiatan perjalanan untuk berekreasi/berlibur (KBBI, 2016). Kegiatan berpariwisata sendiri memiliki banyak dampak positif untuk suatu negara seperti meningkatkan perekonomian masyarakat, memperluas lapangan pekerjaan untuk masyarakat sekitar, banyak dibangun fasilitas dan infrastruktur demi kenyamanan wisatawan, dan meningkatnya devisa negara melalui wisatawan asing (Aridewa, 2019). Meningkatnya industri pariwisata di Indonesia memberikan dampak positif yaitu sebagai penyumbang devisa terbesar bagi Indonesia mengalahkan kelapa sawit (Crude Palm Oil) dengan perolehan sebesar 17,6 miliar USD (Apriliani, 2018).

Pariwisata di Indonesia berperan besar dalam pembangunan nasional, karena sebagai penyumbang devisa terbesar bagi negara (Iswara, 2018). Peningkatan devisa negara Indonesia dapat dilihat melalui tabel data di bawah yaitu jumlah devisa negara Indonesia mengalami peningkatan setiap tahun akibat dari industri pariwisata dari tahun 2016-2018. Meningkatnya industri pariwisata di Indonesia juga disebabkan oleh objek wisata yang beragam sehingga banyak wisatawan asing (mancanegara) dan lokal yang berkunjung. Semakin meningkatnya kunjungan wisata tentu harus diimbangi dengan sarana-sarana pendukung yang merupakan bagian dari industri pariwisata yaitu industri perhotelan. Perhotelan di Indonesia saat ini berkembang semakin pesat, karena dampak dari industri pariwisata di Indonesia. Menurut Chief Operating Officer AccorHotel Indonesia, Malaysia, dan Singapore, Garth Simmons di Jakarta mengatakan bahwa sangat positif dengan industri perhotelan di Indonesia (Ramadhiani, 2018).

Presentase tingkat hunian hotel yang terdapat di Indonesia dari tahun 2008 hingga 2018 yang tiap tahun mengalami peningkatan pengunjung, tetapi dalam tahun 2013-2014 mengalami penurunan sebanyak 0.96\% (Hirschmann, 2019). Industri perhotelan di Jawa Timur juga mengalami naik dan turun. Di beberapa kota di Jawa Timur mengalami penurunan jumlah hotel yang tersedia, tetapi kota yang memiliki banyak objek wisata seperti kota Batu, Surabaya, dan Malang jumlah hotel yang baru dibangun terus bertambah setiap tahun.

Ketua Perhimpunan Hotel dan Restoran di Indonesia (PHRI) Jawa Timur Herry Siswanto mengatakan, pelaku industri perhotelan di Jawa Timur dituntut untuk lebih kreatif dalam menarik perhatian pelanggan agar tidak kalah dengan pesaing lain (Rozack, 2019). pada tahun 2016-2017 memang jumlah hotel di Jawa Timur mengalami penurunan tetapi tidak signifikan, namun jumlah kamar dan tempat tidur atau kasur pada hotel mengalami peningkatan yang signifikan.

Kota Surabaya memiliki banyak jenis hotel yang beroperasi mulai dari hotel melati atau hostel hingga hotel bintang lima. Di kota Pahlawan ini, juga memiliki hotel yang memiliki nilai historis. Misalnya saja, hotel Mojopahit yang berlokasi di Jalan Tunjungan Surabaya. Hotel di zaman kemerdekaan masih bernama Hotel Oranye itu, dulu menjadi tempat sejarah perobekan bendera Belanda, yang dilakukan arek-arek Suroboyo. jumlah hotel berbintang yang ada di kota Surabaya hotel melati atau hostel yang memiliki tarif lebih terjangkau daripada hotel berbintang, memiliki jumlah terbanyak yaitu 111 hostel. Untuk urutan kedua dengan jumlah terbanyak yaitu hotel bintang tiga dengan jumlah 42 hotel. Total seluruh hotel di kota Surabaya yang terdiri dari beberapa jenis yaitu 276.

Seiring dengan perkembangan industri perhotelan di kota-kota, banyak bermunculan hotel-hotel yang dari sisi usia, sudah lebih dari puluhan tahun. Salah satunya adalah Hotel Tanjung Surabaya yang sudah resmi berdiri pada tahun 1984. Hotel Tanjung adalah hotel bintang 2 yang sudah berdiri selama 36 tahun dan masih berjalan hingga saat ini. Kompetisi yang sengit di industri perhotelan mengharuskan Hotel Tanjung meningkatkan performa 
kinerja hotelnya, baik dari eksternal maupun internal. Dalam sisi internal diketahui bahwa setiap karyawan perusahaan merupakan aset dan mitra kerja perusahaan yang harus dijaga dengan baik, karena tanpa mereka perusahaan tidak dapat berjalan dan berkembang (Yonathan, 2019). Agar perusahaan dapat mencapai tujuan, karyawan merupakan salah satu kunci penting dalam keberhasilan tersebut. Pada era seperti ini tidak mudah bagi suatu perusahaan untuk mendapatkan karyawan yang sesuai dengan standar perusahaan yang dapat bersaing secara sehat dengan perusahaan lainnya.

Suatu perusahaan dalam mencapai tujuannya pasti membutuhkan karyawan yang memiliki kemampuan kerja yang baik, dengan kemampuan kerja yang baik karyawan menjadi puas dan semakin loyal dengan perusahaannya. Menurut Safitri (2015) loyalitas berasal dari kata loyal yang memiliki arti setia bisa disebut juga sebagai kesetiaan dan keinginan dalam setiap individu untuk berbuat setia terhadap kelompok, pekerjaan, perusahaan, dan atasan. Loyalitas karyawan tidak mudah untuk didapatkan, oleh karena itu dukungan dan perhatian dari tiap perusahaan berdampak besar terhadap loyalitas karyawan, sehingga terdapat beberapa faktor yang mempengaruhi loyalitas karyawan yaitu kompensasi dan beban kerja yang diberikan kepada karyawan perusahaan.

Faktor pertama yang memiliki pengaruh terhadap loyalitas karyawan yaitu kompensasi. Menurut Larasati (2018) kompensasi adalah sebuah pendapatan yang diterima karyawan baik dalam bentuk uang atau barang sebagai balasan/imbalan dari perusahaan karena karyawan telah melakukan pekerjaan dengan baik. Pemberian kompensasi yang sepadan kepada karyawan atas prestasi kerjanya, sehingga karyawan semakin semangat dalam bekerja, dan menjadi setia terhadap suatu perusahaan. Faktor kedua yang memiliki pengaruh terhadap loyalitas yaitu beban kerja. Menurut Vanchapo (2020) beban kerja merupakan sejumlah pekerjaan yang harus diselesaikan oleh karyawan perusahaan dalam waktu yang ditentukan. Beban kerja sendiri terdiri dari pekerjaan dan lingkungan kerja, akan lebih baik jika beban kerja yang diterima suatu karyawan tidak berlebihan melebihi tenaga dan kemampuan karyawan sehingga karyawan menjadi setia pada perusahaan tempat ia bekerja.

Berdasarkan dari latar belakang yang ada di atas, peneliti tertarik untuk melakukan penelitian yang berjudul "Pengaruh Kompensasi dan Beban Kerja Terhadap Loyalitas Karyawan di Hotel Tanjung Surabaya", yang memiliki tujuan untuk membuktikan kompensasi dan beban kerja berpengaruh terhadap loyalitas karyawan hotel Tanjung Surabaya.

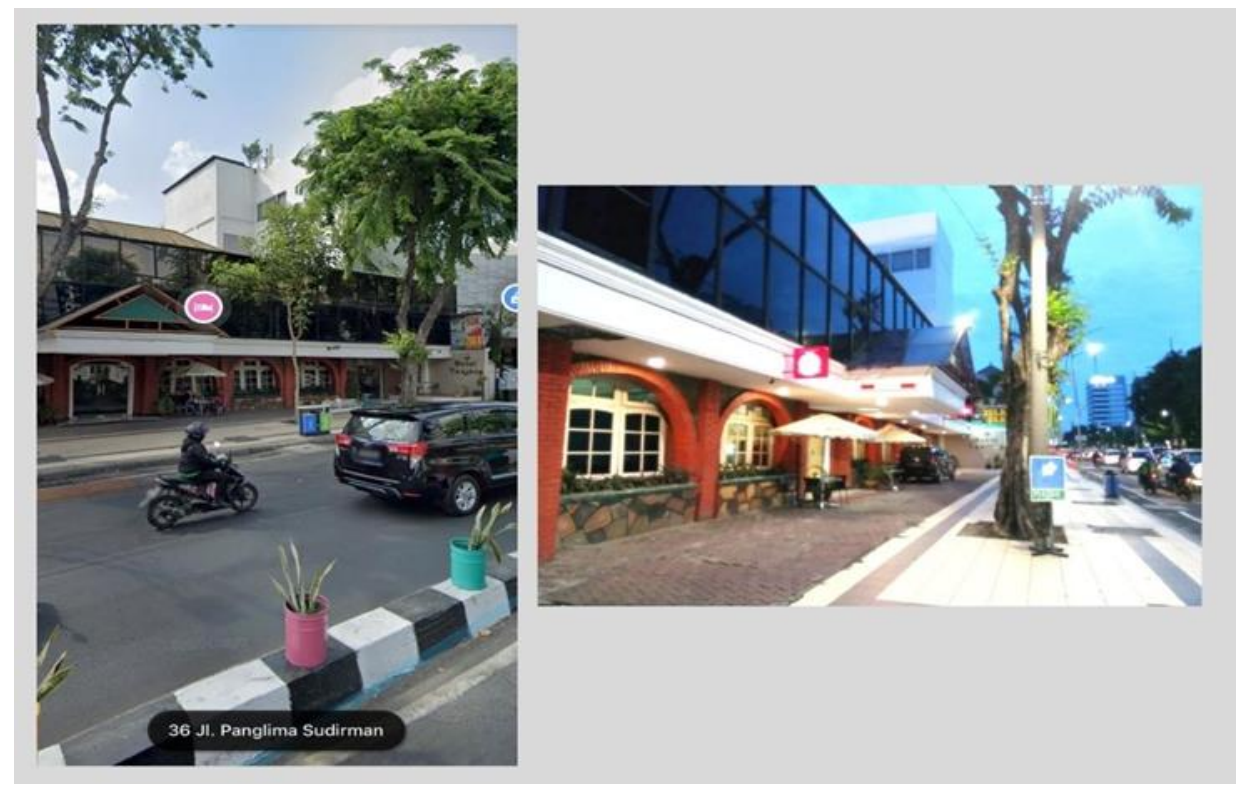

Gambar 1. Tampak depan Hotel Tanjung Surabaya 


\section{PROPAGANDA}

\section{METODE}

Metode yang digunakan peneliti adalah metode penelitian kuantitatif. Menurut Hermawan (2019) penelitian kuantitatif merupakan penelitian yang menekankan fenomenafenomena objektif. Populasi penelitian tersebut yaitu seluruh karyawan yang bekerja di Hotel Tanjung Surabaya yang memiliki 30 karyawan tetap. Sedangkan sampel merupakan bagian kecil yang mewakili kelompok atau keseluruhan yang lebih besar.

Menurut Payadnya dan Jayantika (2018) pada penelitian tersebut pengambilan sampel yang sesuai yaitu menggunakan nonprobability sampling yang merupakan teknik yang tidak memberikan peluang kepada anggota populasi untuk dipilih sebagai sampel. Nonprobability sampling terdiri dari beberapa macam meliputi: sampling Sistematis, sampling Kuota, sampling Aksidental, sampling Purposive, dan sampling Jenuh. Teknik pengambilan sampel yang cocok untuk digunakan dalam penelitian ini yaitu metode sampling jenuh karena jumlah populasi dalam penelitian tersebut sedikit atau subyek kurang dari 100 dan dapat dijangkau oleh peneliti (Rangkuti, 2017). Sampel yang digunakan dalam penelitian ini yaitu sebanyak 30 responden yang merupakan seluruh populasi atau seluruh karyawan Hotel Tanjung Surabaya.

Pengumpulan data yang digunakan dalam penelitian tersebut yaitu data primer dan data sekunder. Data Primer merupakan data yang diperoleh dari hasil kuesioner yang disebarkan kepada responden. Data sekunder merupakan data asli yang diterima dari pihak Hotel Tanjung Surabaya yaitu data karyawan yang bekerja. Metode pengumpulan data yang digunakan adalah membuat kuesioner lalu disebar ke seluruh karyawan yang bekerja di Hotel Tanjung. Menurut Herlina (2019) kuesioner merupakan teknik pengumpulan data yang efisien bila seseorang tahu dengan pasti variabel apa yang akan diukur dan tahu apa yang diharapkan dari responden. Jenis kuesioner yang digunakan dalam penelitian ini yaitu kuesioner tertutup. Kuesioner tertutup merupakan pertanyaan-pertanyaan berbentuk pilihan ganda dan responden tidak memiliki kesempatan untuk memberikan pendapat. Skala yang digunakan untuk kuesioner tertutup ini yaitu skala Likert. Skala Likert merupakan skala yang digunakan untuk mengukur sikap, pendapat, dan persepsi seseorang terhadap sesuatu (Siregar, 2017). Skala Likert yang digunakan yaitu skor 1-4 agar hasil dari penelitian ini valid.

Metode penelitian yang digunakan yaitu kuantitatif, menggunakan regresi linier berganda. Menurut Suyono (2018) regresi linier berganda merupakan perhitungan statistik yang menggunakan variabel terikat $(\mathrm{Y})$ dengan beberapa variabel bebas (X2, X1). Pada penelitian ini, digambarkan X1 merupakan variabel kompensasi, X2 merupakan variabel beban kerja. X1 dan X2 tergolong sebagai variabel bebas, sedangkan Y merupakan variabel Loyalitas yang tergolong sebagai variabel terikat.

\section{HASIL DAN PEMBAHASAN}

\section{Hasil}

Subyek penelitian ini adalah Hotel Tanjung Surabaya, sedangkan obyek dari penelitian ini adalah kompensasi, beban kerja, dan loyalitas karyawan. Hotel Tanjung merupakan hotel berbintang dua yang sudah berdiri pada tahun 1984 dan berada di Jalan Panglima Sudirman nomor 43-45, Surabaya. Subyek dari penelitian ini adalah Hotel Tanjung Surabaya yang didirikan oleh almarhum Bapak Anwari Mukri pada tahun 1984 yang terletak di Jalan Panglima Sudirman no 43-45, Surabaya. Hotel Tanjung adalah hotel berbintang dua yang memiliki lokasi strategis yaitu berada di tengah kota Surabaya, membutuhkan waktu 30 menit menuju Bandara Juanda, 20 menit menuju terminal bus, dan 10 menit menuju stasiun kereta api. Hotel Tanjung saat ini dijalankan oleh Ibu Endang Andayani putri dari Bapak Anwari Mukri sang pendiri. 
Hotel Tanjung memiliki 56 kamar yang terdiri dari beberapa kelas yaitu mulai dari standard junior (8 kamar), standard senior (15 kamar), standard (15 kamar), superior (12 kamar), deluxe (3 kamar), dan yang terakhir suite (3 kamar) merupakan kamar dengan kelas paling tinggi.

Selain kamar hotel juga menyediakan fasilitas-fasilitas lain seperti restoran Anggrek yang menyediakan berbagai hidangan khas Indonesia yang dapat dinikmati oleh penginap maupun tamu dari luar hotel, dan ruangan pertemuan yang dilengkapi dengan layar besar, mic, meja panjang, kursi yang dapat digunakan untuk melakukan berbagai rapat atau pertemuan penting. Saat ini hotel Tanjung memiliki 30 karyawan yang terdiri dari berbagai jabatan yaitu General Manager, Duty Manager, Human Resource Department, Head Marketing, Receptionist (5 orang), Accounting ( 2 orang), Kepala Koki, Koki (4 orang), Waiter (3 orang), Sekuriti (3 orang), Housekeeping Teknik (2 orang), Housekeeping Roomboy (5 orang), Laundry. Berikut gambar yang merupakan tampak depan hotel Tanjung Surabaya.

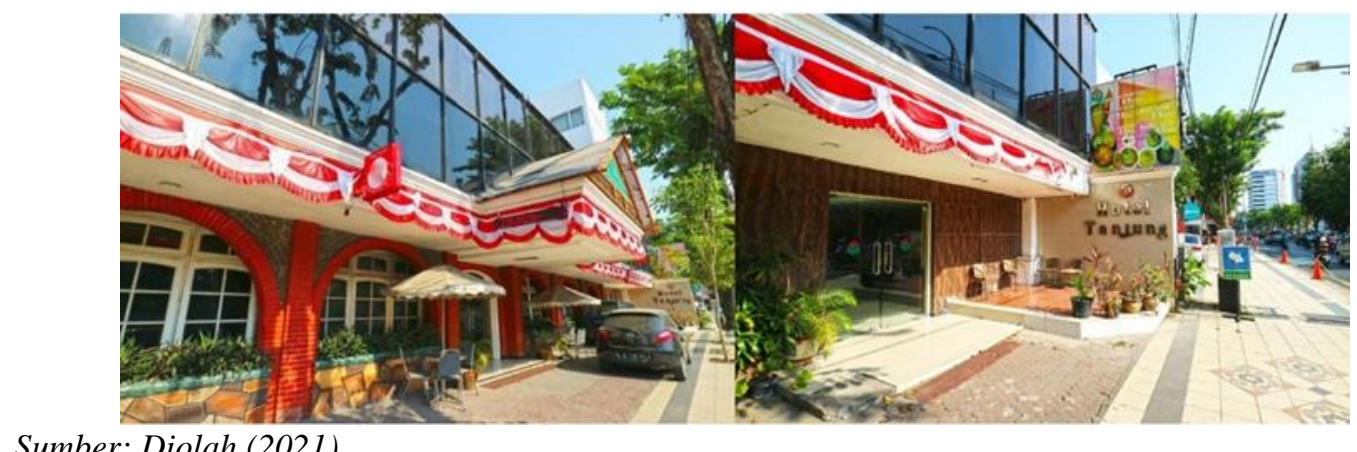

Sumber: Diolah (2021)

Gambar 2. Tampak Depan Hotel Tanjung Surabaya

Pada tabel 1 di bawah dapat dilihat bahwa dari total seluruh karyawan hotel Tanjung yaitu terdapat 19 responden atau 63,3\% yang berjenis kelamin pria dan untuk 11 responden atau $36,7 \%$ yang berjenis kelamin wanita. Dapat disimpulkan dalam tabel tersebut bahwa responden pria lebih dominan karena jumlahnya lebih banyak dari responden wanita.

Tabel 1. Data Responden berdasarkan Jenis Kelamin

\begin{tabular}{ccll}
\hline No & Jenis Kelamin & Jumlah Responden & Persentase (\%) \\
\hline 1. & Pria & 19 & $63,3 \%$ \\
2. & Wanita & 11 & $36,7 \%$ \\
\hline Total & & $\mathbf{3 0}$ & $\mathbf{1 0 0 \%}$ \\
\hline \multicolumn{2}{l}{ Sumber: Diolah (2021) } & &
\end{tabular}

Tabel 2. Data Responden berdasarkan Usia

\begin{tabular}{|c|c|c|c|}
\hline No & Usia & Jumlah Responden & Persentase $(\%)$ \\
\hline 1. & 21-30 tahun & 4 & $13,3 \%$ \\
\hline 2. & $31-40$ tahun & 7 & $23,3 \%$ \\
\hline 3. & 41-50 tahun & 14 & $46,7 \%$ \\
\hline 4. & $>50$ tahun & 5 & $16,7 \%$ \\
\hline & Total & 30 & $100 \%$ \\
\hline
\end{tabular}

Pada tabel 2 di atas tabel usia responden, dapat dilihat bahwa responden yang berusia 21-30 tahun terdapat 4 responden atau 13,3\%, usia 31-40 tahun sebanyak 7 responden atau $23,3 \%$, usia 41-50 tahun sebanyak 14 responden atau 46,7\%, dan usia di atas 50 tahun sebanyak 5 responden atau 16,7\%. Dapat disimpulkan dalam tabel usia responden yaitu karyawan dengan usia 41-50 tahun yang jumlahnya paling banyak. 


\section{PROPAGANDA}

Pada tabel 3 di bawah tabel lama bekerja dapat dilihat bahwa sebanyak 3 responden atau 10\% sudah bekerja selama 5-10 tahun, 1 responden atau 3,3\% sudah bekerja selama 1015 tahun, 4 responden atau 13,3\% sudah bekerja selama 15-20 tahun, dan 22 responden atau $73,3 \%$ sudah bekerja lebih dari 20 tahun. Disimpulkan bahwa responden terbanyak yaitu yang sudah bekerja lebih dari 20 tahun sebanyak 22 responden.

Tabel 3. Data Responden berdasarkan Lama Bekerja

\begin{tabular}{cccc}
\hline No & $\begin{array}{c}\text { Lama } \\
\text { Bekerja }\end{array}$ & $\begin{array}{c}\text { Jumlah } \\
\text { Responden }\end{array}$ & $\begin{array}{c}\text { Persentase } \\
(\boldsymbol{\%})\end{array}$ \\
\hline 1. & $5-10$ tahun & 3 & $10 \%$ \\
2. & $10-15$ tahun & 1 & $3,3 \%$ \\
3. & $15-20$ tahun & 4 & $13,3 \%$ \\
4. & $>20$ tahun & 22 & $73,3 \%$ \\
\hline \multicolumn{2}{r}{ Sumber: Diolah $(2021)$} & $\mathbf{3 0}$ & $\mathbf{1 0 0 \%}$ \\
\hline
\end{tabular}

\section{Uji Validitas dan Reabilitas}

Hasil uji validitas dilakukan untuk setiap instrumen pada variabel kompensasi, beban kerja, dan loyalitas karyawan, yang menunjukkan bahwa seluruh item kuesioner memiliki nilai korelasi > 0,361, sehingga kuesioner yang digunakan dinyatakan valid. Kemudian, Uji reliabilitas berfungsi untuk mengukur seberapa akurat kuesioner dapat menunjukkan informasi yang terjadi di lapangan. Selain itu, uji reabilitas juga dilakukan pada penelitian ini, Uji reliabilitas tersebut menggunakan Cronbach's Alpha sebagai alat ukur uji tersebut. Kuesioner dapat dikatakan reliabel apabila nilai Cronbach's Alpha $>0,60$. Uji realibilitas membuktikan bahwa nilai pada variabel kompensasi menunjukkan nilai Cronbach's Alpha sebesar 0,897, pada variabel beban kerja menunjukkan nilai Cronbach's Alpha sebesar 0,851, dan pada variabel loyalitas karyawan menunjukkan nilai Cronbach's Alpha sebesar 0,902. Dapat disimpulkan bahwa seluruh variabel memiliki nilai > 0,6 maka dinyatakan reliabel dan dapat digunakan dalam penelitian.

Tabel 4. Hasil Uji Realibilitas

\begin{tabular}{ccc}
\hline Variabel & Cronbach's Alpha & Kesimpulan \\
\hline Kompensasi (X1) & 0,897 & Reliable \\
Beban Kerja (X2) & 0,851 & Reliable \\
Loyalitas Karyawan $(\mathrm{Y})$ & 0,902 & Reliable \\
\hline
\end{tabular}

Sumber: Diolah (2021)

\section{Uji Asumsi Klasik}

Berdasarkan tabel 5 uji normalitas di bawah diketahui bahwa nilai signifikansi uji tersebut adalah 0,997 sehingga nilai tersebut $>0,05$ kesimpulannya nilai residual berdistribusi secara normal. Hal ini membuktikan bahwa asumsi normalitas terpenuhi sehingga regresi dalam model linier berganda dapat dilakukan. Pada tabel 6 di bawah uji multikolinearitas menunjukkan nilai tolerance sebesar 0,356 untuk kompensasi dan 0,356 untuk beban kerja yang nilainya lebih besar dari 0,1 . Nilai VIF pada setiap variabel juga menunjukkan nilai kurang dari 10 yang berarti tidak terjadi multikolinearitas pada model regresi. Pada tabel 7 uji heterokedastisitas di bawah dapat dilihat bahwa variabel X1 memiliki nilai sig 0,444 dan X2 memiliki nilai sig 0,613. Dapat disimpulkan bahwa kedua variabel di atas memiliki nilai sig > 0,05 maka tidak terjadi heterokedastisitas. Berdasarkan tabel 8 di bawah dapat dilihat bahwa hasil uji linieritas pada variabel kompensasi menunjukkan angka 0,000 yang berarti $<0,05$. Dapat disimpulkan bahwa variabel kompensasi memiliki hubungan linear dengan variabel 
loyalitas karyawan. Berdasarkan tabel 8 di bawah dapat dilihat bahwa hasil uji linieritas pada variabel beban kerja menunjukkan angka 0,000 yang berarti $<0,05$. Dapat disimpulkan bahwa variabel beban kerja memiliki hubungan linear dengan variabel loyalitas karyawan.

Tabel 5. Uji Normalitas

\begin{tabular}{cc}
\hline \multicolumn{2}{c}{ One-Sample Kolmogorov-Smirnov Test } \\
\hline Kolmogorov-Smirnov Z & .401 \\
Asymp. Sig. (2-tailed) & .997 \\
\hline Sumber: Diolah (2021)
\end{tabular}

Tabel 6. Uji Multikolinieritas

\begin{tabular}{ccc}
\hline Variabel & Tolerance & VIF \\
\hline Kompensasi (X1) & 0,356 & 2,807 \\
Beban Kerja (X2) & 0,356 & 2,807 \\
\hline & Dependent Variable: Loyalitas Karyawan & \\
\hline Sumber: Diolah (2021) & &
\end{tabular}

Tabel 7. Uji Heterokedastisitas

\begin{tabular}{clc}
\hline Variabel & Sig & Keterangan \\
\hline Kompensasi (X1) & .444 & Tidak terjadi heterokedastisitas \\
Beban Kerja (X2) & .613 & Tidak terjadi heterokedastisitas \\
\hline Sumber: Diolah (2021) & &
\end{tabular}

Tabel 8. Uji Linieritas

\begin{tabular}{lll}
\hline Variabel & Linearity Sig. & Keterangan \\
\hline Kompensasi (X1) & .000 & Memiliki Hubungan Linear \\
Beban Kerja (X2) & .000 & Memiliki Hubungan Linear \\
Sumber: Diolah $(2021)$ & &
\end{tabular}

\section{Analisis Regresi Linear Berganda}

Dapat dilihat pada tabel 9 berdasarkan perhitungan analisis regresi linier berganda bahwa variabel X1 menunjukkan nilai 0,378 memiliki nilai yang lebih rendah dibanding dengan nilai variabel X2 yaitu 0,649. Berdasarkan tabel 9 nilai hasil uji analisis regresi liner pada variabel X1 yaitu sebesar 0,378. Dapat disimpulkan apabila kompensasi yang diberikan oleh hotel Tanjung kepada karyawan sesuai atau memuaskan maka loyalitas karyawan dapat meningkat sebesar 37,8\%. Berdasarkan tabel 9 nilai hasil uji regresi linier pada variabel X2 yaitu 0,649. Dapat disimpulkan apabila beban kerja yang diberikan oleh hotel Tanjung kepada karyawan sesuai atau tidak berlebihan maka loyalitas karyawan dapat meningkat sebesar $64,9 \%$.

Tabel 9. Uji Analisis Regresi Linear Berganda

\begin{tabular}{cccc}
\hline \multirow{2}{*}{ Model } & \multicolumn{2}{c}{ Unstandardized Coefficients } & Standardized Coefficients \\
\cline { 2 - 4 } (Constant) & B & Std. Error & Beta \\
\hline Kompensasi (X1) & 8.934 & 3.216 & .495 \\
Beban Kerja (X2) & .378 & .121 & .422 \\
\hline
\end{tabular}

Sumber: Diolah (2021)

\section{Koefisien Korelasi dan Determinasi}

Berdasarkan tabel 10 koefisien korelasi di bawah dapat dilihat bahwa nilai $\mathrm{R}$ yaitu 0,871 apabila diubah ke persentase menjadi $87,1 \%$. Kesimpulan bahwa variabel bebas pada uji tersebut memiliki hubungan kuat dengan variabel terikat karena nilai $\mathrm{R} 0,871>0,5$. 


\section{PROPAGANDA}

Berdasarkan tabel 4.17 nilai $\mathrm{R}$ square yaitu 0,759 atau $75,9 \%$, sehingga variabel bebas (kompensasi, beban kerja) dalam penelitian ini memiliki pengaruh pada variabel terikat sebesar $75,9 \%$ dan sebanyak $24,1 \%$ merupakan pengaruh dari variabel lain selain variabel bebas dalam penelitian ini.

Tabel 10. Uji Koefisien Korelasi dan Determinasi

\begin{tabular}{cccc}
\hline Model & R & R Square & Adjusted R Square \\
\hline 1 & $.871^{\mathrm{a}}$ & .759 & .741 \\
\hline Sumber: Diolah $(2021)$ & & &
\end{tabular}

Uji F

Pada tabel 11 di bawah menunjukkan bahwa nilai Fhitung sebesar 42,534 yang berarti Fhitung > Ftabel $(42,534>3,35)$ dan memiliki nilai signifikansi 0,000<0,05. Dengan demikian dapat disimpulkan bahwa variabel kompensasi dan beban kerja berpengaruh secara signifikan terhadap variabel loyalitas karyawan.

Hipotesis uji $\mathrm{F}$ dalam penelitian ini yaitu:

H0: Tidak ada pengaruh signifikan antara variabel bebas kompensasi (X1) dan beban kerja (X2) terhadap variabel terikat loyalitas karyawan (Y).

H1: Ada pengaruh signifikan antara variabel bebas kompensasi (X1) dan beban kerja (X2) terhadap variabel terikat loyalitas karyawan (Y).

\begin{tabular}{|c|c|}
\hline \multicolumn{2}{|c|}{ Tabel 11. Uji F } \\
\hline $\mathbf{F}$ & Sig. \\
\hline 42,534 & $.000^{\mathrm{a}}$ \\
\hline
\end{tabular}

\section{Uji T}

Berdasarkan tabel 12 di bawah dapat dilihat bahwa variabel kompensasi (X1) memiliki $\mathrm{t}$ hitung sebesar 3,127, sehingga $t$ hitung $>\mathrm{t}$ tabel $(3,127>2,052)$. Pada bagian signifikansi variabel kompensasi memiliki signifikasi 0,004 sehingga nilai tersebut $<0,05(\alpha)$. Dapat disimpulkan bahwa $\mathrm{H} 0$ ditolak dan $\mathrm{H} 1$ diterima, sehingga variabel bebas kompensasi memiliki pengaruh signifikan terhadap variabel terikat loyalitas karyawan.

Pada tabel 12 di bawah dapat dilihat variabel beban kerja (X2) memiliki nilai t hitung sebesar 2,669 sehingga $t$ hitung $>\mathrm{t}$ tabel $(2,669>2,052)$. Sedangkan pada bagian signifikansi (sig) variabel beban kerja memiliki nilai sebesar 0,013 sehingga nilai tersebut $<0,05(\alpha)$. Dapat disimpulkan bahwa $\mathrm{H} 0$ ditolak dan $\mathrm{H} 1$ diterima, sehingga variabel bebas beban kerja memiliki pengaruh signifikan terhadap variabel terikat loyalitas karyawan.

Tabel 12. Uji T

\begin{tabular}{lll}
\hline Variabel & $\mathbf{t}$ & Sig. \\
\hline Kompensasi (X1) & 3.127 & .004 \\
Beban Kerja (X2) & 2.669 & .013 \\
\hline Sumber: Diolah (2021) & &
\end{tabular}

\section{Pembahasan}

Pada bagian deskripsi jawaban responden untuk variabel kompensasi butir pernyataan dengan nilai mean terendah terletak pada butir X1.7 dengan nilai 2,80 yaitu mengenai fasilitas asuransi kesehatan yang diberikan kepada karyawan dan kedua pada butir X1.13 dengan nilai 2,83 yaitu mengenai THR yang diterima karyawan harus sesuai dengan ketentuan dari pemerintah. Standar deviasi terendah terletak pada butir X1.9 dengan nilai 0,662 mengenai 
fasilitas yang diberikan perusahaan kepada karyawan seperti makan dan transportasi yang berarti jawaban dari responden lebih konsisten/ tidak beragam. Variabel bebas kedua yaitu beban kerja nilai mean terendah terletak pada butir X2.4 dengan nilai 3,00 mengenai beban kerja karyawan tidak melebihi batas waktu yang ditetapkan 8 jam per hari dan kedua pada butir X2.5 dengan nilai 3,00 mengenai pergantian jam kerja/shift antar karyawan yang tepat waktu. Nilai standar deviasi terendah terletak pada butir X2.4 dengan nilai 0,587 mengenai beban kerja karyawan, tidak melebihi batas waktu yang ditetapkan dalam peraturan perusahaan (delapan jam per hari). Dengan demikian jawaban responden cenderung konsisten/ tidak beragam.

Variabel kompensasi (X1) berpengaruh positif signifikan terhadap loyalitas karyawan (karyawan Hotel Tanjung Surabaya). Diperkuat dengan adanya penelitian terdahulu dari Heryati (2016) menyatakan bahwa kompensasi berpengaruh positif signifikan terhadap loyalitas karyawan dalam penelitian tersebut juga menyatakan bahwa pemberian gaji, insentif, dan tunjangan yang sesuai mempengaruhi loyalitas karyawan. Selain itu menurut Gustina (2019) kompensasi melalui uji t dan uji f membuktikan berpengaruh signifikan terhadap loyalitas karyawan. Dengan demikian, maka simpulan yang dapat disampaikan bahwa, variabel bebas kompensasi memiliki pengaruh positif signifikan terhadap variabel terikat loyalitas karyawan.

Variabel beban kerja berpengaruh positif signifikan terhadap loyalitas karyawan (karyawan Hotel Tanjung Surabaya). Adanya dukungan dari penelitian terdahulu oleh Heryati (2016) yang menyatakan bahwa variabel beban kerja berpengaruh positif signifikan terhadap loyalitas karyawan, beban kerja yang sesuai dan tidak berlebihan meningkatkan loyalitas karyawan. Menurut Adhitia, Suryoko, dan Widiartanto (2014) yaitu pekerjaan yang sesuai bidang, jam kerja sesuai ketentuan, dan beban kerja yang sesuai kemampuan karyawan meningkatkan loyalitas karyawan. Dengan demikian, simpulannya bahwa variabel bebas beban kerja memiliki pengaruh positif signifikan terhadap variabel terikat loyalitas karyawan.

Kompensasi dan beban kerja berpengaruh positif signifikan terhadap loyalitas karyawan, dapat dibuktikan melalui hasil uji f yang menunjukkan nilai 42,534 > 3,35 (f hitung $>\mathrm{f}$ tabel) dan memiliki nilai signifikansi 0,000 < 0,05 sehingga dapat disimpulkan bahwa variabel bebas kompensasi dan beban kerja berpengaruh positif signifikan terhadap variabel terikat loyalitas karyawan.

\section{PENUTUP}

Variabel kompensasi (X1) berpengaruh positif signifikan terhadap loyalitas karyawan (karyawan Hotel Tanjung Surabaya). Dapat dibuktikan karena melalui penelitian ditemukan hasil $\mathrm{t}$ hitung $>\mathrm{t}$ tabel $(3,127>2,052)$ dan memiliki nilai signifikansi $0,004<0,05$, sehingga H0 ditolak dan H1 diterima. Melalui hasil uji analisis linier berganda didapat hasil sebesar 0,378, maka variabel loyalitas karyawan dapat meningkat sebesar 37,8\% sehingga semakin tinggi kompensasi yang diterima maka semakin tinggi loyalitas karyawan tersebut. Variabel kompensasi dapat meningkat yaitu dengan memberikan gaji dan insentif yang sesuai kinerja, memberikan penghargaan pada karyawan berprestasi.

Variabel beban kerja berpengaruh positif signifikan terhadap loyalitas karyawan (karyawan Hotel Tanjung Surabaya). Dapat dibuktikan karena melalui penelitian ditemukan hasil t hitung $>\mathrm{t}$ tabel $(2,669>2,052)$ dan memiliki nilai signifikansi $0,013<0,05$, yang berarti $\mathrm{H} 0$ ditolak dan $\mathrm{H} 1$ diterima. Hasil uji analisis linier berganda menunjukkan nilai sebesar 0,649 maka variabel loyalitas karyawan dapat meningkat sebesar 64,9\% sehingga beban kerja yang diberikan sesuai dengan kemampuan dan tidak berlebihan maka loyalitas karyawan dapat meningkat. 


\section{PROPAGANDA}

Berdasarkan hasil pembahasan yang telah dilakukan mengenai pengaruh kompensasi dan beban kerja terhadap loyalitas karyawan (karyawan Hotel Tanjung Surabaya), maka didapatkan hasil bahwa variabel bebas kompensasi memiliki pengaruh positif signifikan terhadap variabel terikat loyalitas karyawan. Selain itu, penelitian ini juga menyimpulkan bahwa variabel bebas beban kerja memiliki pengaruh positif signifikan terhadap variabel terikat loyalitas karyawan serta variabel bebas kompensasi dan beban kerja juga berpengaruh positif signifikan terhadap variabel terikat loyalitas karyawan.

\section{DAFTAR PUSTAKA}

Adhitia, P., Suryoko, S., \& Widiartanto. (2014). Pengaruh kompensasi, lingkungan kerja, dan beban kerja terhadap loyalitas karyawan melalui kepuasan kerja.

Apriliani, D. (2018, Desember 23). Good News From Indonesia. Retrieved Oktober 4, 2020, from Good News From Indonesia: https://www.goodnewsfromindonesia.id/2018/12/23/kemajuan-pariwisata-indonesiapenyumbang-devisa-terbesar-indonesia

Aridewa, A. I. (2019, Oktober 29). Kompasiana. Retrieved September 30, 2020, from Kompasiana:

https://www.kompasiana.com/albanyilfad/5db7fd45d541df35521b10f2/dampakpariwisata-terhadap-perekonomian-masyarakat

Gustina, D. D. (2019). Pengaruh Kompensasi, Beban Kerja dan Work Life Balance terhadap Loyalitas Karyawan dengan Kepuasan Kerja Sebagai Variabel Moderasi.

Herlina, V. (2019). Panduan Praktis Mengolah Data Kuesioner Menggunakan SPSS. Jakarta : Elex Media Komputindo.

Hermawan, I. (2019). Metodologi Penelitian Pendidikan (Kualitatif, Kuantitatif, dan Mixed Method). Cilombang: Hidayatul Quran.

Heryati, A. (2016). Pengaruh kompensasi dan beban kerja terhadap loyalitas karyawan di Departemen Operasi PT Pupuk Sriwidjaja Palembang. Jurnal Ecoment Global, 56-75.

Hirschmann, R. (2019, April 24). statista. Retrieved february 29, 2020, from statista: https://www.statista.com/statistics/866796/indonesia-occupancy-rate-in-star-hotels/

Iswara, A. J. (2018, Desember 26). Good News From Indonesia. Retrieved Maret 12, 2020, from Good News From Indonesia: https://www.goodnewsfromindonesia.id/2018/12/26/tantangan-pariwisata-indonesiadi-2019-dan-siasatnya

Larasati, S. (2018). Manajemen Sumber Daya Manusia . Yogyakarta : Deepublish .

Ramadhiani, A. (2018, April 4). Jakarta, Kompas. Retrieved february 20, 2020, from Kompas: https://properti.kompas.com/read/2018/04/04/170000421/potensi-bisnis-hotel-dariwisatawan-domestik-lebih-menjanjikan

Rangkuti, A. A. (2017). Statistika Inferensial untuk Psikologi dan Pendidikan. Yogyakarta: Kencana.

Rozack, A. (2019, April 10). Jawa Pos Ekonomi Surabaya. Retrieved february 20, 2020, from Radar

Surabaya: https://radarsurabaya.jawapos.com/read/2019/04/10/130835/pertumbuhan-hotelberbintang-di-daerah-meningkat

Safitri, R. (2015). Pengaruh kompensasi terhadap loyalitas karyawan Pt Putera Lautan Kumala Lines Samarinda. eJournal Administrasi Bisnis, 651-652. Retrieved September 30, 2020, from https://ejournal.hi.fisip-unmul.ac.id/site/wpcontent/uploads/2015/08/Jurnal\%20Rahmadana\%20Safitri\%20(08-24-15-05-56$\underline{50) . p d f}$ 
Suyono. (2018). Analisis Regresi untuk Penelitian . Yogyakarta : Deepublish.

Vanchapo, A. R. (2020). Beban Kerja dan Stres Kerja. Pasuruan: Qiara Media .

Vanchapo, A. R. (2020). Beban Kerja dan Stress Kerja . Pasuruan: Penerbit Qiara Media .

Yonathan, I. (2019, April 30). Kompasiana. Retrieved September 30 , 2020, from Kompasiana: https://kupang.tribunnews.com/2019/04/30/iwan-karyawan-itu-aset-perusahaan-danmitra-kerja 